\title{
Analysis of Students' Multiple representation-based Problem - solving Skills
}

\author{
Army Al Islami Ali Putra ${ }^{1}$, Nonoh Siti Aminah ${ }^{2}$, Ahmad Marzuki ${ }^{3}$ \\ ${ }^{1}$ Physics Education, Universitas Sebelas Maret, Indonesia \\ Email: armyalislami@gmail.com \\ ${ }^{2}$ Physics Education, Universitas Sebelas Maret, Indonesia \\ Email: nonoh@staff.uns.ac.id \\ ${ }^{3}$ Physics Education, Universitas Sebelas Maret, Indonesia \\ Email: ahmadmarzuki@staff.uns.ac.id
}

(Received: November-2019; Reviewed: January-2020; Accepted: March-2020; Available online: March 2020; Published: April-2020)

\begin{abstract}
This study aims to analyze the profile of students' problem - solving skills based on multiple representation in senior high school. Problem - solving skills in solving multiple representation are very important in learning Physics. The subjects of this study were 101 students of class XII MAN 1 Ngawi. The method used in this research was quantitative descriptive method. Indicators of the problem - solving abilities that were used included approaches, visuals, applications, and procedures. The types of representation in this research instrument were verbal, figures, graphic and mathematic. The results showed that the problem - solving skills related to the indicator of approach with the form of multiple representation questions got percentages of $36 \%$ (verbal), $42 \%$ (figural), $24 \%$ (graphical), and 43\% (mathematical). The visual indicators showed the percentages of 44, 29, 38, and 0 for verbal, figural, graphical, and mathematical respectively. Then the indicators of procedures obtained $36 \%$ for the verbal, $30 \%$ for the figures, $35 \%$ for the graphics, and $0 \%$ for the mathematics. Thus, it can be concluded that problem-solving skills possessed by students are different in terms of the percentage each indicator got in the multiple representation test.
\end{abstract}

Keywords: multiple representation; problem - solving skills; thermodynamics.

\section{INTRODUCTION}

Education is a way to provide a high quality of human resources with skills, sensitivity, and critical thinking (Cahyani and Setyawati 2016). Therefore, in this era, education is expected to develop students' skills early so that they can solve problems in their daily life. (Barak 2017) mentioned four skills need to be mastered by each student namely ways of thinking, ways for working, tools for working and living in the world. Skills in the group of ways of thinking is a reasoning skill like the ability to solve problems (Grifiin and Mcgaw 2012).
Problem - solving skill is the ability to identify and formulate problems and find out an effective solution (Haryani and Nur'aeni 2012). Therefore, it can be concluded that problem - solving skills is an ability possessed by somebody to do identification and formulation on a problem through a solving strategy.

Problem - solving skills are generally perceived difficult by students. Therefore, they are necessary for them to be applied in learning. (Russefendi 1991) stated that problem - solving skills are not only demanded in Math subject, but also all lessons related to problem - solving in daily life like Physics. Physics is a conditional 
subject which means that each new concept requires prior understanding and knowledge because concepts are correlated each other (Rusilowati 2006). Therefore, physics subject needs relatively high intellectuality like problem - solving skills. (Mundilarto 2002) also stated that skills needed in understanding Physics are calculation, manipulation, observation, and critical problem - solving.

The ability to solve a problem through multiple representation is very important in the Physics learning process. The external representation that is applied in learning can reduce students' cognitive load in solving problems, and habituate students to write answers in detail. Through the application of problem solving skills, students will be able to solve the problems they are facing. Earlier studies show that the application of multiple representation gives positive impact in Physics learning. (Van Heuvelen and Zou 2001), argued that multiple representation approach can improve students' analytical skills in learning materials about works and energy. (Mayer 2003) stated that multiple representation can help students to build their conceptual understanding more deeply. As the consequence, they can more understand the concepts they study. Furthermore, (Rosengrant, Etkina, and Van Heuvelen 2007) stated that being skillful in utilizing various representations can assist students to solve problems. Besides problem - solving skills, students must be able to solve problems to get a better understanding. According to (Ainswort 1999), the application of multiple representation can help students to understand complex physics concepts. It is supported by (De Cock 2012) in Representation Use and Strategy Choice in Physics Problem solving showing that students' achievement is significantly affected by representation they use and students can complete a test given in three different representation formats including verbal, figure, and graph. Besides that, multiple representation has some functions like to explore students' knowledge in each representation, to scaffold them to build their understanding, and to know students' thoughts and reasoning (Carolan, Prain, and Waldrip 2008).

(Waldrip, Prain, and Carolan 2006) defined multiple representation as practices to representing again (re-representing) the same concepts through various forms including descriptive representation modes (verbal, graph, table), experimental, mathematical, figurative (pictorial, analogy, and metaphor), kinesthetic, visual and / or action / operational modes. Representation is an entity in which all thought is believed to take place. This entity delivers specific information about what is learned by figuring out ideas, objects, systems, events, and processes, which is widely known as representation (Gilbert 2010).

This study aimed to investigate students' problem - solving skills according to a multiple representation-based test.

\section{METHOD}

This study employed a quantitative descriptive method. According to (Arikunto 2013), the descriptive study aims at collecting information about the status and the real condition of a phenomenon when the study is being undertaken. Besides that, this study employed a quantitative approach to make the data applicable to all research populations (Sugiyono. 2009). Qualitative descriptive study is the activity to collect information broadly about an event or the real condition of a variable. This study was carried out in MAN 1 Ngawi. The total number of respondents was 101 from three classes. An essay test was used as an instrument. The data were collected using the test instrument containing 10 questions. Indicators of multiple representation according to (Yusup 2019) include (1) Verbal Description, (2) Figure/diagram, (3) Graph, and (4) Mathematics.

Indicators of the problem - solving skills as stated by $G$ Polya: (1) Understanding problems, (2) Designing plan, (3) executing the plan, and (4) reviewing. The rubric of the problem - solving skills is shown in Table 11. 
Table 1. The Rubric of Problem - solving Skills.

\begin{tabular}{|c|c|c|c|c|}
\hline \multirow{2}{*}{ Indicators } & \multicolumn{3}{|c|}{ Scores } & \multirow[b]{2}{*}{0} \\
\hline & 3 & 2 & 1 & \\
\hline $\begin{array}{l}\text { Visualization/ } \\
\text { problem } \\
\text { Description }\end{array}$ & $\begin{array}{l}\text { The answer } \\
\text { contains the correct } \\
\text { and complete } \\
\text { description of the } \\
\text { problems. }\end{array}$ & $\begin{array}{l}\text { One part of the } \\
\text { problem description } \\
\text { is not correct or } \\
\text { complete }\end{array}$ & $\begin{array}{l}\text { More than one part } \\
\text { of the description is } \\
\text { incomplete or } \\
\text { contains errors }\end{array}$ & $\begin{array}{l}\text { All description is } \\
\text { incorrect and } \\
\text { contains errors }\end{array}$ \\
\hline $\begin{array}{l}\text { Physics } \\
\text { Approach }\end{array}$ & $\begin{array}{l}\text { The answer uses } \\
\text { the correct and } \\
\text { complete approach } \\
\text { of Physics }\end{array}$ & $\begin{array}{l}\text { A physics approach } \\
\text { that is used is less } \\
\text { accurate or } \\
\text { incomplete }\end{array}$ & $\begin{array}{l}\text { More than one } \\
\text { physics principle is } \\
\text { less accurate or } \\
\text { incomplete }\end{array}$ & $\begin{array}{l}\text { All chosen } \\
\text { concepts or } \\
\text { principles are } \\
\text { inappropriate }\end{array}$ \\
\hline $\begin{array}{l}\text { Special } \\
\text { Application } \\
\text { of Physics } \\
\text { Concepts }\end{array}$ & $\begin{array}{l}\text { The answer uses } \\
\text { the correct, } \\
\text { complete and } \\
\text { appropriate } \\
\text { application of } \\
\text { Physics concept }\end{array}$ & $\begin{array}{l}\text { One of the uses of } \\
\text { the Physics concept } \\
\text { is incomplete or } \\
\text { contains errors }\end{array}$ & $\begin{array}{l}\text { More than one } \\
\text { physics concept is } \\
\text { incomplete or } \\
\text { contains errors }\end{array}$ & $\begin{array}{l}\text { All specific } \\
\text { applications are } \\
\text { inappropriate or } \\
\text { contain errors }\end{array}$ \\
\hline $\begin{array}{l}\text { Mathematical } \\
\text { Procedures }\end{array}$ & $\begin{array}{l}\text { The mathematical } \\
\text { procedures were } \\
\text { appropriate and } \\
\text { complete }\end{array}$ & $\begin{array}{l}\text { The mathematical } \\
\text { procedures are } \\
\text { complete but contain } \\
\text { few errors }\end{array}$ & $\begin{array}{l}\text { One of the math } \\
\text { procedures is } \\
\text { incomplete or } \\
\text { contains errors }\end{array}$ & $\begin{array}{l}\text { All mathematical } \\
\text { procedures are } \\
\text { incomplete and / } \\
\text { or contain errors }\end{array}$ \\
\hline $\begin{array}{l}\text { Logical } \\
\text { conclusion }\end{array}$ & $\begin{array}{l}\text { All answers to } \\
\text { problems are clear, } \\
\text { focus, and logical }\end{array}$ & $\begin{array}{l}\text { Answers of } \\
\text { problems are clear } \\
\text { and focus but } \\
\text { contain an error }\end{array}$ & $\begin{array}{l}\text { More than one } \\
\text { answer is not clear, } \\
\text { not focus or not } \\
\text { consistent }\end{array}$ & $\begin{array}{l}\text { All answers are } \\
\text { not clear, not } \\
\text { focus, and not } \\
\text { consistent }\end{array}$ \\
\hline
\end{tabular}

(Hidayat et al. 2017)

The calculation of problem - solving skill scores was performed using equation (1) to determine the percentage of students' problem solving skill achievement. The percentages of students' achievement on problem - solving skills in each indicator are as presented in Table 2.

Table 2. Predicates of Students' Mathematical Problem - solving Skills

\begin{tabular}{lcc}
\hline & Categories & Criteria \\
\hline$A=$ very satisfying & $81 \%-100 \%$ \\
$B=$ satisfying & $61 \%-80 \%$ \\
$C=$ quite satisfying & $41 \%-69 \%$ \\
$D=$ less satisfying & $21 \%-40 \%$ \\
$\mathrm{E}=$ not satisfying & $0 \%-20 \%$ \\
\hline
\end{tabular}

\section{RESULTS AND DISCUSSION}

The material investigated in this study was thermodynamics. It is a Physics concept that must be mastered by students (Rahmawati, Wiyono, and Syuhendri 2017) considering that it is highly related to daily lives. (Mulop, Yusof, and Tasir 2012) stated that thermodynamics is a subject related to energy and is important to understand before studying natural phenomena. Thermodynamics has an important role in humans' lives. (Hassan and Mat 2005) stated that thermodynamics as a basic knowledge which is related to energy has become an important part of the curriculum of engineering. It is also supported by (Kulkarni and Tambade 2013) that thermodynamics is an important topic to be studied in Physics because it is broadly applied in 
science and technology.

According to a study conducted on 19 October 2019, students' problem - solving skills are varied based on the forms of questions. A multiple representation - based question produces various answers. After students receiving the test, we got the data about the rate of their answer in each indicator as presented in table 3 .

Table 3. Percentages of Multiple representation-based Problem - solving skills

\begin{tabular}{lrrcc}
\hline & Verbal & \multicolumn{1}{c}{ Figural } & Graphic & Mathematical \\
\hline Approach & $36 \%$ & $42 \%$ & $24 \%$ & $42 \%$ \\
Visualization & $44 \%$ & $29 \%$ & $38 \%$ & - \\
Application & $47 \%$ & $37 \%$ & $31 \%$ & - \\
Procedure & $36 \%$ & $30 \%$ & $35 \%$ & - \\
\hline
\end{tabular}

In table 3, it can be seen that the indicator of problem - solving skill approaches in the form of verbal multiple representation was completed by $36 \%$ of students. The visualisation indicator got the rate of $44 \%$. The percentage of problem solving skills in the indicator of the application was $47 \%$ and in the indicator of procedure was $36 \%$. Multiple representation in the form of figures using problem - solving skills, related to the approach got the percentage of $42 \%$. The visual indicator got $29 \%$, the application indicator got $37 \%$, and the procedure indicator got 30\%. Furthermore, mathematical multiple representation in the indicator of approach was completed by $42 \%$ of students. Indicators of visualization, application and procedure showed $0 \%$. While multiple representation in the form of a graph, in the indicator of approach obtained $24 \%$, in the indicator of visual was $38 \%$, in the indicator of application $=31 \%$, and the problem - solving skills (procedure indicator) got $35 \%$. The percentages of multiple representation based problem - solving skill can be seen in Figure 1.

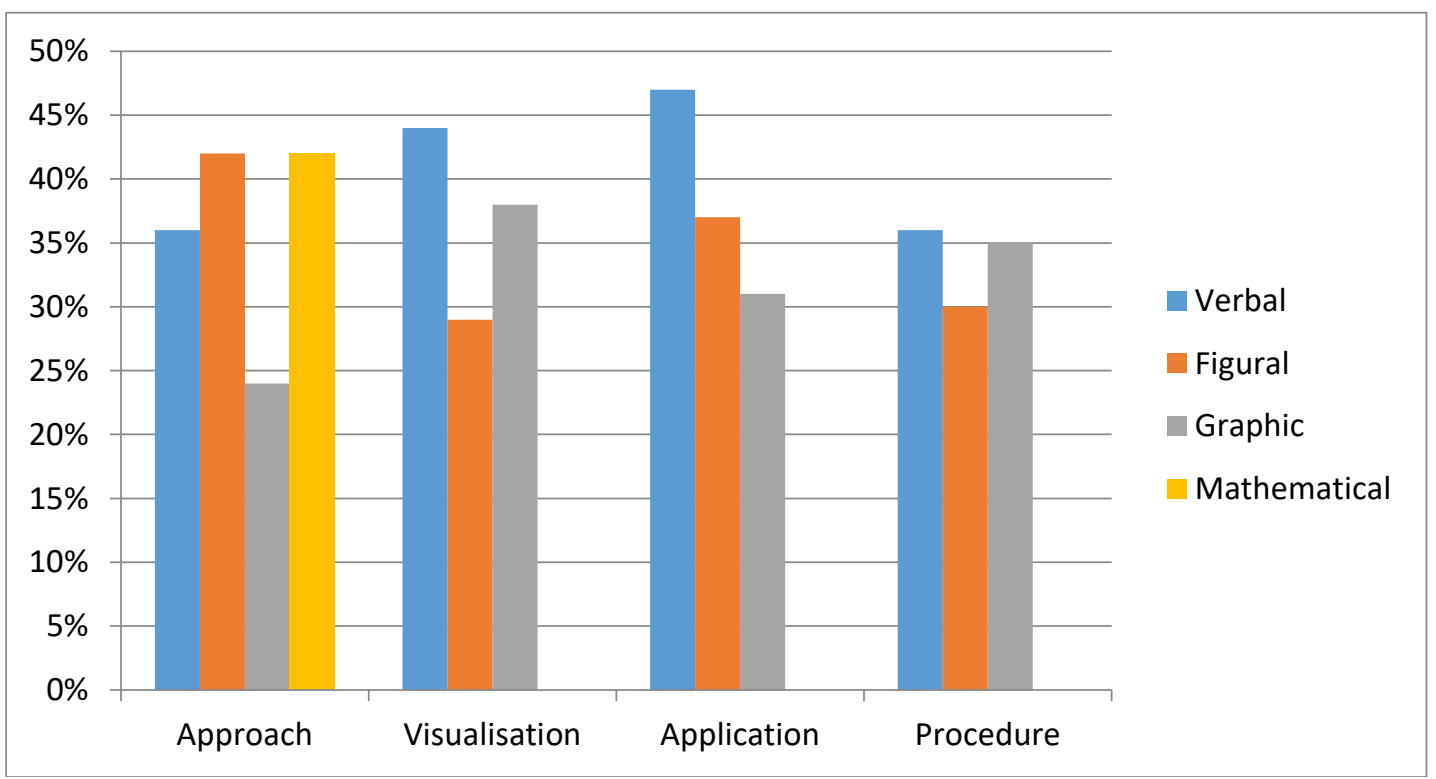

Figure 1. Percentages of multiple representation based problem - solving skills

\section{Discussion}

According to research findings, it can be seen that problem - solving skills in the indicator of test approach with figural and mathematical forms got higher percentages than other forms of questions which were at $42 \%$ for each. While the figural was (36\%) and graphical was (24\%) only. It was because students preferred to study figures and had an understanding that the thermodynamics test in Physics is always related with mathematics and calculation. 
The second indicator of problem - solving skills is visualization. It is to see the students' ability to visualize or to identify what students know about the thermodynamics questions. In this indicator, the verbal questions had a higher percentage compared to others which was $44 \%$, while the figural (29\%), graphics (38\%) and mathematical $(0 \%)$. It was because multiple representation test with verbal questions was easier to be understood by students and was clearer for them. It was different from questions in the forms of figure or graph which only showed a picture or chart accompanied by numbers that lead confusion to students to read and understand them. It is due to students' limitation to transfer sentences of a word problem into mathematics model and their low confidence in working on questions (Netriwati 2016).

The third indicator was the application that was to know basic equations that students had known related to the questions. The form of the question that got the highest percentage is the verbal (47\%), meaning students more understood verbal questions to determine the equation or formula they should use.

The fourth indicator is the procedure that aimed to identify stages taken by students in doing the test until they can come up with correct answers. In this indicator, the verbal questions got the highest percentage (36\%). It was because students better understood the questions to follow the procedures.

Some students who tried to answer questions carefully ended up with clear and consistent answers. Besides that, they were able to answer questions according to the problem solving skills indicators because they tried to read and understand the content of the questions before answering them. According to (Mustofa and Rusdiana 2016), it might be because many students do not understand the concepts of Physics that have been taught. It is supported by (Fajarudin 2012) that problem - solving skills require a mastery of the concepts as the foundation. The mastery of the concept can be abstracted as the basis to achieve skills of the problem - solving, creative and critical thinking, and decision making.

Problem - solving skills in the test had four indicators. Questions about approach had purpose to direct student in working the next question. The visualization indicator emphasized on what students knew about the questions. In this case, students were expected to see and read questions and be able to write everything they knew about the questions. Next, the indicator of applications reflected students' ability to write down and apply equations that would be used to solve problems in the questions. In this stage, students should be able to write the formula that they would use. The procedure indicator was to measure students' ability to work on questions using the equation they had written until they could end up with the correct answer. In this step, students should be able to follow steps to solve the questions so that they could answer them correctly. (Suhandi and Wibowo 2012) stated that the application of multiple representation can sharpen and strengthen students' concepts and reduce their hesitation because the essence of a concept can be clear when presented through various representations. (Sajadi, Amiripour, and Rostamy-Malkhalifeh 2013) mentioned that problem - solving is an important element for students in collaborating problems they find in their real lives.

\section{CONCLUSIONS AND SUGGESTION}

Based on the findings and discussion, it can be concluded that problem - solving skills related to the indicators of approach with questions in the form of multiple representation got the percentages of $36 \%$ (verbal), $42 \%$ (figural), $24 \%$ (graphical), and $43 \%$ (mathematical). In indicators of visual, the percentages are $44 \%$ (verbal), $29 \%$ (figural), 38\% (graphical), and $0 \%$ (mathematical). The percentages of application indicators were 47 (verbal), 37 (figural), 31 (graphical), and 0 (mathematical). Then, in the indicators of procedures, we obtained the percentages of $36 \%$ (verbal), 30\% (figural), 35\% (graphical), and 0\% (mathematical). These research findings can be taken as a reference to improve the teaching strategy so that students can solve problems in thermodynamics subject. Students' problem solving skills can be improved through various ways which in this case are the use of models that can train students high order thinking skills so that they can solve various problems accurately according to correct procedures. Therefore, we can conclude that students' have a different problem - solving skills according to the percentages each indicator got in the multiple representation test.

\section{REFERENCES}

Ainswort, Shaaron. 1999. "The Functions of 
Multiple Representations." Computer \& Education 33: 131-52.

Arikunto. 2013. Prosedur Penelitian, Suatu Pendekatan Praktik. Jakarta: Rineka CIpta.

Barak, Miri. 2017. "Science Teacher in the Twenty First Century: A Pedagogical Framework for Technology-Integrated Social Constructivism." Research in Science Education 47 (2): 283-303.

Cahyani, Hesti, and Ririn Wahyu Setyawati. 2016. "Pentingnya Peningkatan Problem - solving skills Melalui PBL Untuk Mempersiapkan Generasi Unggul Menghadapi MEA." In PRISMA, Prosiding Seminar Nasional Matematika, 151-60.

Carolan, Jim, Vaughan Prain, and Bruce Waldrip. 2008. "Using Representations for Teaching and Learning in Science." Teaching Science 54 (1): 18-23.

Cock, Mieke De. 2012. "Representation Use and Strategy Choice in Physics Problem - solving." Physical Review Special Topics - Physics Education Research 8 (2): $1-15$. https://doi.org/10.1103/PhysRevSTPE R.8.020117.

Fajarudin, M. F. 2012. Pengaruh Model Pembelajaran Inkuiri Terbimbing Berbantuan Website Terhadap Penguasaan Konsep Dan Problem solving skills Siswa Kelas X Pada Topik Listrik Arus Searah. Banndung: Program Pascasarjana UPI.

Gilbert, John K. 2010. "The Role of Visual Representations in the Learning and Teaching of Science : An Introduction." Asia-Pacific Forum on Science Learning and Teaching 11 (1): 1-20.

Grifiin, Patrick, and Barry Mcgaw. 2012. Assesment and Teaching of 21st Century Skill. 1st ed. Netherlands: Springer.

Haryani, Sri, and Nur'aeni. 2012. "Studi Deskriptif Tentang Problem - solving skills Pada Peserta Didik Kelas VIII SMP Negeri I Baturraden Tahun Ajaran 2011/2012." PSYCHO IDEA, no. 1: 2530.
Hassan, O, and R. Mat. 2005. "A Comparative Study of Two Different Approaches in Teaching Thermodynamics. Faculty of Chemical and Natural Resources Engineering, UTM-JB." In Proceedings of the 2005 Regional Conference on Engineering Education.

Heuvelen, Alan Van, and Xueli Zou. 2001. "Multiple Representations of WorkEnergy Processes." American Journal $\begin{array}{lll}\text { of Physics } 69 & \text { (2): 184-94. }\end{array}$ https://doi.org/10.1119/1.1286662.

Hidayat, Syarif Rokhmat, Anggi Hanif Setyadin, Hermawan Hermawan, Ida Kaniawati, Endi Suhendi, Parsaoran Siahaan, and Achmad Samsudin. 2017. "Pengembangan Instrumen Tes Keterampilan Pemecahan Masalah Pada Materi Getaran, Gelombang, Dan Bunyi." Jurnal Penelitian \& Pengembangan Pendidikan Fisika 3 (2): 157-66. https://doi.org/10.21009/1.03206.

Kulkarni, Vd, and Ps Tambade. 2013. "Assessing the Conceptual Understanding about Heat and Thermodynamics at Undergraduate Level." European Journal Of Physics Education 4 (2): 9-16. http://ejpe.erciyes.edu.tr/index.php/EJP E/article/view/101.

Mayer, Richard E. 2003. "The Promise of Multimedia Learning: Using the Same Instructional Design Methods across Different Media." Learning and Instruction 13 (2): 125-39. https://doi.org/10.1016/s09594752(02)00016-6.

Mulop, Normah, Khairiyah Mohd Yusof, and Zaidatun Tasir. 2012. "A Review on Enhancing the Teaching and Learning of Thermodynamics." In Procedia Social and Behavioral Sciences, 56:703-12.

https://doi.org/10.1016/j.sbspro.2012.0 9.706.

Mundilarto. 2002. Kapita Selekta Pendidikan Fisika. Yogyakarta: FMIPA UNY.

Mustofa, M. Hariri, and Dadi Rusdiana. 
2016. "Profil Problem - solving skills Siswa Pada Pembelajaran Gerak Lurus." Jurnal Penelitian \& Pengembangan Pendidikan Fisika 02 (2): $15-22$. https://doi.org/10.21009/1.02203.

Netriwati. 2016. "Analisis Problem - solving skills Matematika Berdasarkan Teori Polya Ditinjau Dari Pengetahuan Awal Mahasiswa Iain Raden Intan Lampung." Al-Jabar 7 (2): 181-90.

Rahmawati, D, K Wiyono, and Syuhendri. 2017. "Analisis Pemahaman Konsep Termodinamika Mahasiswa Pendidikan Fisika Menggunakan Instrumen Survey of Thermodynamic Process and First and Second Laws ( STPFaSL )." Jurnal Ilmu Fisika Dan Pembelajarannya 1 (1): 17-27.

Rosengrant, David, Eugenia Etkina, and Alan Van Heuvelen. 2007. "An Overview of Recent Research on Multiple Representations." In AIP Conference Proceedings, 883:149-52. https://doi.org/10.1063/1.2508714.

Rusilowati, A. 2006. "Profil Kesulitan Belajar Fisika Pokok Bahasan Kelistrikan Siswa Sma Di Kota Semarang." Jurnal Pendidikan Fisika Indonesia 4 (2): 100-106. https://doi.org/10.15294/jpfi.v4i2.163.

Russefendi. 1991. "Penilaian Pendidikan Dan Hasil Belajar Khususnya Dalam Pembelajaran Matematika Untuk Guru Dan Calon Guru." Tidak Diterbitkan.

Sajadi, Maryam, Parvaneh Amiripour, and Mohsen Rostamy-Malkhalifeh. 2013. "The Examining Mathematical Word Problems Solving Ability under Efficient Representation Aspect." Mathematics Education Trends and Research 2013: 1-11. https://doi.org/10.5899/2013/metr-
00007.

Sugiyono. 2009. Metode Penelitian Pendidikan (Pendekatan Kuantitatif, Kualitatif, Dan R\&D). Bandung: Alfabeta.

Suhandi, A, and F C Wibowo. 2012. "Pendekatan Multi representation Dalam Pembelajaran Usaha-Energi Dan Dampak Terhadap Pemahaman Konsep Mahasiswa." Jurnal Pendidikan Fisika Indonesia 8: 1-7.

Utami, Ratna Widianti, and Dhoriva Urwatul Wutsqa. 2017. "Analisis Problem solving skills Matematika Dan SelfEfficacy Siswa SMP Negeri Di Kabupaten Ciamis." Jurnal Riset Pendidikan Matematika 4 (2): 166-75. https://doi.org/10.21831/jrpm.v4i2.148 97.

Waldrip, Bruce, Vaughan Prain, and Jim Carolan. 2006. "Learning Junior Secondary Science through MultiModal Representations." Electronic Journal of Science Education 11 (1): 87-107.

Yusup, M. 2019. "Multi representation Dalam Pembelajaran Fisika." In Http://Eprints.Unsri.Ac.Id/1607/1. https://doi.org/.1037//00332909.I26.1.78. 